\title{
Economic Competition in Kosovo: An Empirical Analysis
}

Submitted 2/12/18, $1^{\text {st }}$ revision 18/1/19, $2^{\text {nd }}$ revision 20/2/19 accepted 26/3/19

\author{
Gani Asllani ${ }^{1}$, Jonathan Spiteri ${ }^{2}$, Simon Grima ${ }^{3}$
}

\begin{abstract}
:
Purpose: With this article we aim to lay out the results of an investigation on the development and protection of economic competition in Kosovo, focusing specifically on the analysis of the level of competition in the Gjilan region. We deal with the legislative aspects of the competition in the sensitive sectors (banks, insurance, gas stations and pharmacies) where the competition is damaged and present the measures for improvement based on the EU practices.

Design/Methodology/Approach: The used method is to lay out a realistic picture of (1) the level of competition development, (2) the areas where competition is undermined, (3) the general business knowledge about the functioning and enforcement of the law on competition protection, and (4) the concrete measures to be taken in order for competition to function based on the rules of the market economy.

Findings: Results show that on average, respondents believe that their sector is relatively well-regulated and competitive, although there are clear areas of improvement, notably with regards to the difficulties encountered when doing business, the effectiveness of Kosovo's existing legislative framework and the existence of monopoly power within most sectors.

Practical Implications: The role of competition authorities in curbing anti-competitive practices needs strengthening, as attested by the results obtained, and more needs to be done when it comes to tackling collusive business practices, particularly among pharmacies and banks.

Originality/Value: The most vulnerable areas where competition is violated are telecommunications, transport, insurance, energy, procurement, petroleum products, banking and financial services and pharmacies sectors. Therefore, there is a need for interinstitutional cooperation, especially cooperation with and empowerment of, economic regulators.
\end{abstract}

Keywords: Developments, competition, monopolies, competition policy, Kosovo, Gjilan Region.

JEL Classification: F12, R11, R58.

Paper type: Research article.

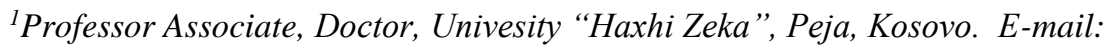
gani.asllani@unhz.eu

${ }^{2}$ Lecturer, University of Malta, Department of Insurance, Faculty of Economics, Management and Accountancy, jonathan.v.spiteri@um.edu.mt

${ }^{3}$ Simon Grima. University of Malta, Head, Department of Insurance, Faculty of Economics, Management and Accountancy, corresponding author, simon.grima@um.edu.mt
} 


\section{Introduction}

The creation of a market economy and the free operation of market mechanisms is an important objective for sustainable economic development. The realization of this objective requires the decision-makers to create economic and competition policies, which are adapted to legislation and that will influence economic growth through on the one hand (1) a competitive market and on the other hand (2) eliminate the behaviour that harms the free market (Voigt, 2009). The sound competition policy and the encouragement of competitiveness among market participants have multiple positive effects on the state's economy, businesses and consumers (Krakowski, 2005, Sengupta and Dube, 2008). A very important segment for consolidating economies such as Kosovo's economy is the creation of a market-oriented economy that should be accompanied by increased productivity and competitiveness (Asllani, 2017).

Market opening and creation of free market access is of vital importance for sustainable economic development (Scopelliti, 2009). Competition policy and its defence occupy a very important place in the economic policies of developed and the consulted countries, therefore they are given special treatment (Don, Kemp and Sinderen, 2008). The Kosovar market is a relatively small market, and the concentration of trading activities is in the hands of a few players and these have a big impact on the final consumer. Therefore, this implies the need for the state to ensure the proper functioning of the regulatory mechanisms of the market. The most vulnerable areas where competition is violated are telecommunications, transport, insurance, energy, procurement, petroleum products, banking and financial services and pharmacies sectors.

Therefore, there is a need for inter-institutional cooperation, especially cooperation with and empowerment of, economic regulators (OECD, 2015). In transition economies, the three types of anti-competitive practices: (1) prohibited agreements, (2) abuse of dominant position and (3) control of mergers, fall under the competition law (DG, Competition, 2017).

\section{Literature review}

According to standard economic theory, competition is defined as a market situation in which suppliers strive for consumers in a way that induces them to become more efficient and capable of offering a wide variety of products and services at lower prices. Competition should be the basis for determining the quality of goods and services provided, based on certain standards that will be offered to consumers. Competition creates an economic environment where firms can operate freely in achieving these objectives, while consumers, in turn, benefit from the prices set based on the interaction between demand and supply forces (Gavil, Kovacic and Baker, 2002).

Competition brings dynamism, so it ensures that businesses are under constant 
pressure to deliver the best possible goods and services to customers at the best possible prices (Winston and Crandall, 2003). In this way, it affects the improvement of the allocation of production factors and the growth of the welfare of society (Gerber, 2001). Competition forces firms to always improve their products and promote the development of new technologies. It should eliminate as much as possible reduced choices or scarce innovations. It promotes initiatives and innovations as well as adopting new technologies (Aghion, Bloom, Blundell, Griffith and Howitt, 2002). The competition also hampers the creation of monopolies because they have been detrimental both to the economy and to the consumer because of the latter benefit from the possibility of choices, quality, fair prices and new products (Romero, 2003; Voigt, 2009; Petersen, 2013).

Competition affects investment growth by eliminating various barriers and thereby increasing the employment rate. Increasing the economic efficiency of different entities and increasing economic growth and disciplining the management of these entities. Competition is the main driver of competitiveness among firms and leads to a country's economic growth (Dutz and Hayri, 1999). It forces outbid firms to market inefficient firms and redistributes production resources from failed firms to more powerful competitors.

The implementation of the 'Law on Protection of Competition' by the Institutions for Protection of Competition, other commercial laws and the development of proper anti-trust policies in order to promote it amongst the contestants in the market and the growth of competitiveness is a continuous work-in-progress and benefits all market players (Dutz and Vagliasindi, 2000). It can be said that the protection and development of competition is realized through its two main pillars: Competition Law and Competition Policies (UNCTAD, 2010). Within the Competition Law are included: controlling cartels, controlling concentration and controlling abuse of dominant position. While competition policies include: economic activities of economic regulators as well as economic policy areas where competition is affected (Sengupta and Dube, 2008).

\section{The State of Kosovo}

Kosovo is situated in the middle of South-East Europe, positioned in the centre of Balkan Peninsula. It represents an important crossroad between South Europe and Middle Europe, the Adriatic Sea and the Black Sea. Kosovo's area is $10,887 \mathrm{~km}^{2}$. It is forecasted that Kosovo has 1,907,592 residents and the density of the population is around 159 persons per $\mathrm{km}^{2}$, and it is divided into 38 Municipalities.

Kosovo was under UNMIK administration since 1999. During this time Kosovo was administered by United Nations Mission and Provisional Institutions of SelfGovernment, while the security issues were trusted to NATO- (KFOR) troops. On $17^{\text {th }}$ February 2008, Kosovo's Assembly has declared the independence of Kosovo. On 2011 Kosovo has been organized with a general registration of the population, 
apartments and households, by the Statistical Office of Kosovo and came out with the results of this registration (Kosovo Agency of Statistics, 2011).

\subsection{Legal Aspect of the Competition Control- Law on Protection of Competition}

The Constitution of Kosovo, article 10 lays down an economic system of Kosovo as a system based in a free market economy and freedom of economic activity (Constitution of the Republic of Kosovo, 2007). Free market means the economy where the decision about production and consumption are taken by individuals and private companies. The price, quantity and production method is set out by the market. To fulfil this function the market must have competition rules. A free market economy where the production opportunities are kept away from companies with a dominant position in the market, whether they are private or public should not be allowed (Regulation No. 1/2003, EC).

When a company holds a considerable dominant position in the market, consumers are not able to have an opinion in the setting of prices (Asllani, 2016). Therefore, one needs to analyse (a) the past (is performed ex-post), and (b) a prognosis for the future (performed ex-ante) to determine the effect of the dominant position of companies and concentration of companies.

Law on protection of competition respects shares of control ex-ante and ex-post, by treating forbidden agreements and excluding by prohibition, abuse of the companies in a dominant position and where concentration is anticipated. In the other part, the law lays out the competition authority as the responsible body for law implementation.

The competition in Kosovo is currently regulated by the Law on Protection of Competition nr. 03/1-229, of October $7^{\text {th }} 2010$ (official gazette of Republic of Kosovo). This law amended the Law 2004/36. The law sets out the opportunity of market monitoring using two methods: (a) by controlling the actions of enterprises, and (b) by controlling the market structure.

\subsection{The Region of Gjilan}

The study focuses on the analysis of economic competitiveness in the Gjilan region. Equal to the level of development of Economic Competition in Kosovo and Gjilan Region faces the same challenges, so by researching some of the most vulnerable sectors where competition is being affected is attempted to give a clear picture of the level of competition development and law enforcement for the protection of competition.

Kosovo's first level of local government is divided into seven administrative regions, which are: Pristina, Mitrovica, Gjilan, Ferizaj, Prizren, Gjakova and Peja region (Statistical Agency of Kosovo, 2014). 
Figure 1. The Kosovo is divided in units

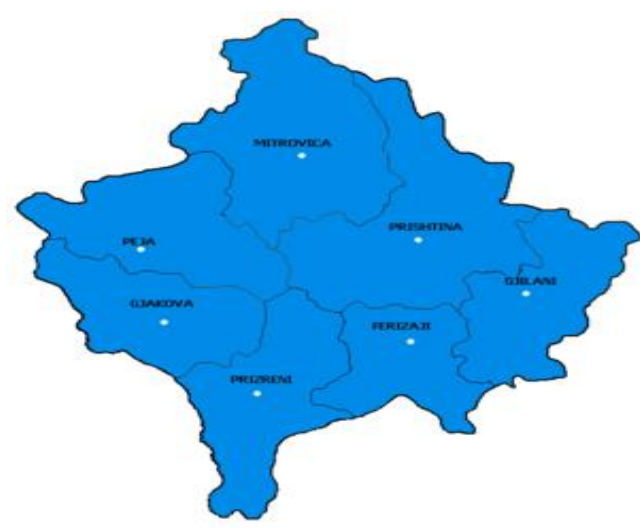

Figure 2. Gjilan Region

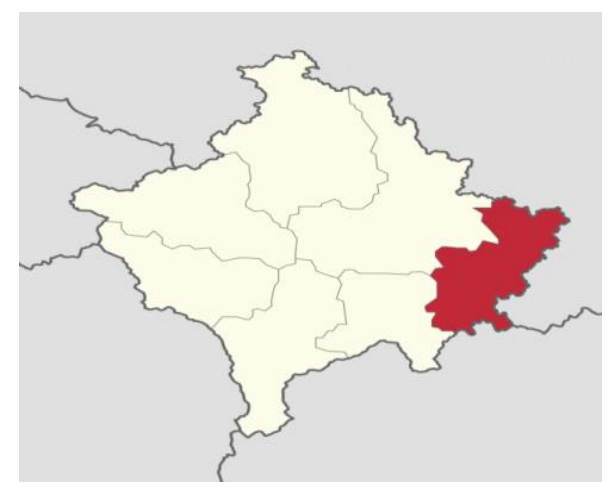

Source: Statistical Agency of Kosovo.

The District of Gjilan is one of the seven districts (the higher-level administrative divisions) of Kosovo. The district of Gjilan has a total of 6 municipalities: Gjilan, Kamenica and Vitia as a bigger municipality as well as Ranilug, Partesh and Kllokot municipality with population and small territory (inhabited by Serbian minority). The research is focused on the three major municipalities while other municipalities in terms of competition, market size and market impact do not have any relevance.

\section{Methodology and Data}

Self-administered, structured face-to-face interviews were carried out with 71 participants, including 23 respondents from Pharmacies, 11 from Gas Stations, 19 from Banks and 18 from Insurance Firms. The sample of participants in four sectors was determined using a non-probability purposive sampling method (Tongco, 2007). We chose these four sectors since, when looking at the experience of developing countries and the Balkan region and given the market size of the economy (geographical market), the product and the number of players, they can influence competition and have the possibility to control and determine the market conditions within the region. We ceased carrying out surveys when we started to obtain similar answers and reached saturation (i.e., at 71 participants) (Morse, 1995). We ensured that participants at a minimum held a high-school diploma and had an understanding of economic competition in Kosovo.

The interview consisted of 2 parts; one with six generic closed-ended questions related to competition and an open-ended question to collect further comments; and the other with five different questions specific to each of the four sectors. In this paper, we shall focus on the general questions related to competition, where respondents were required to answer 'Yes', 'Partly' or 'No'. The data collected was 
stored quantitatively except for the open-ended answers. The answers were given a number from 1 to 3 reflecting Yes=1, Partly $=2$ and No=3 for the generic questions. We maintained the same order for the specific answers provided in part 2, e.g., Regulated=1, Partly=2, Deregulated=3. The data were analysed using the Stata software package, version 15.

\section{Empirical analysis}

We start by grouping survey responses according to the type of firm under observation, namely pharmacies, insurance companies, banks and gas stations. Figure 3 below shows the extent to which each respondent believes that their sector is heavily regulated or not, with 1 denoting 'Regulated', 2 'Partly' and 3 'Deregulated'. As seen below, on average most respondents believe that their sector is relatively regulated, with the mean score in each case falling short of the midpoint. A Kruskal-Wallis test reveals no significant differences across sectors (chi-squared statistic $=5.447 ; \mathrm{p}=0.1418$ ), suggesting that the extent of regulation within each sector is broadly similar.

Figure 3. Extent to which respondents believe that sector is regulated

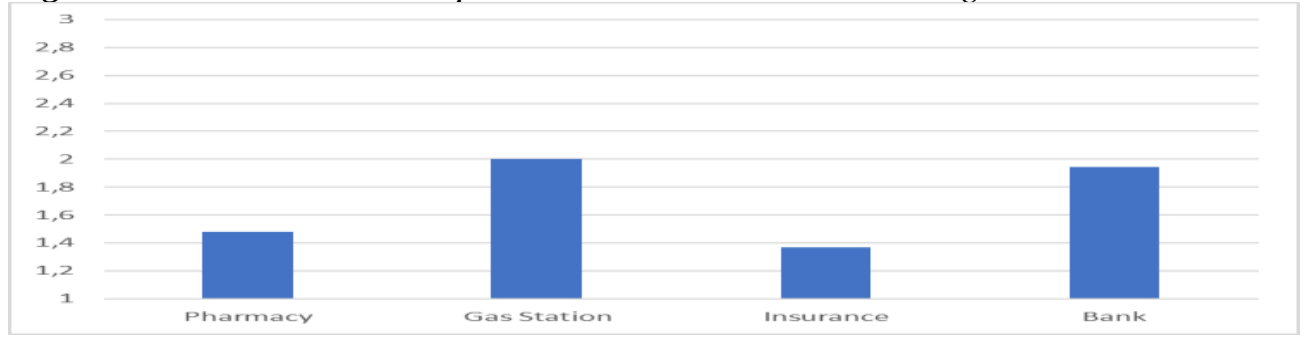

Figure 4 also looks at the extent to which firms believe that their sector is competitive or not, with 1 denoting 'Full Competition', 2 'Partly' and 3 'No Competition'. As seen below, on average most respondents believe that their sector is competitive, with only gas stations opting on average for 'partly' competitive. The Kruskal-Wallis test indicates no significant differences across means (chi-squared statistic=3.636; $\mathrm{p}=0.3035)$, thus once again showing that competition levels within each sector are relatively similar.

Figure 4. Extent to which respondents believe that sector is competitive

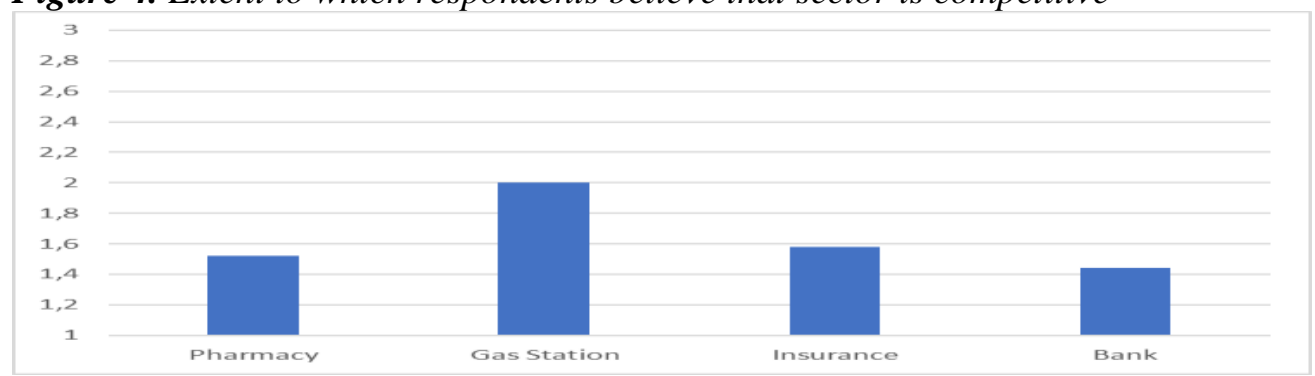


We now turn to the sectoral responses derived for each of the key business questions posed in the survey. Figure 5 shows the extent to which respondents encounter difficulties when conducting their business. As seen below, most respondents indicated that they operate in a business environment with clear impediments and difficulties. This is consistent across all sectors, as attested by the Kruskal-Wallis test which shows no significant differences across means (chi-squared statistic=2.369; $\mathrm{p}=0.4994)$.

Figure 5. To what extent do you encounter difficulties when doing business in the Gjilan Region? (1 - 'Yes'; 2 - 'Partly'; 3 - 'No')

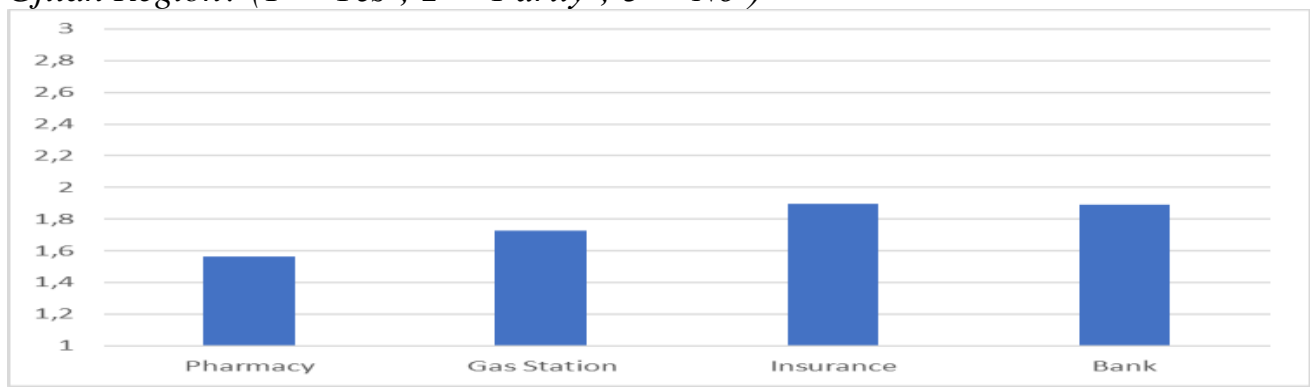

Figure 6 shows the extent to which firms believe that Kosovo has a sufficientlystrong legal framework in place. Once again, we find agreement across the board, only this time the majority lean towards rejecting the notion that Kosovo's legal system is sound, with no significant differences across sectors (chi-squared statistic=1.503; $\mathrm{p}=0.6815$ ).

Figure 6. To what extent do you believe that Kosovo has a sound legal framework? (1-'Yes'; 2- 'Partly'; 3- 'No')

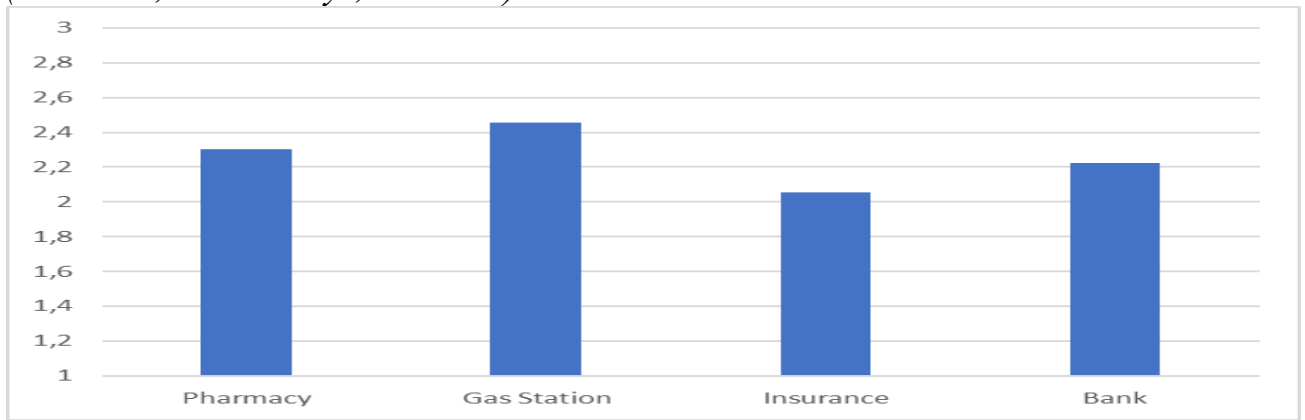

We now turn to awareness regarding the existence of law no. 3/L which protects against anti-competitive practices and seeks to preserve free enterprise in Kosovo. As seen below in Figure 7, there is a strong awareness of this law across most sectors, with the Kruskal-Wallis test statistic not statistically-significant (chi-squared statistic=4.913; $\mathrm{p}=0.1782$ ), although it is notable that gas stations on average have low awareness in this regard. 
Figure 7. To what extent are you aware of law no. 3/L on competition in Kosovo? (1 - 'Yes'; 2 - 'Partly'; 3 - 'No')

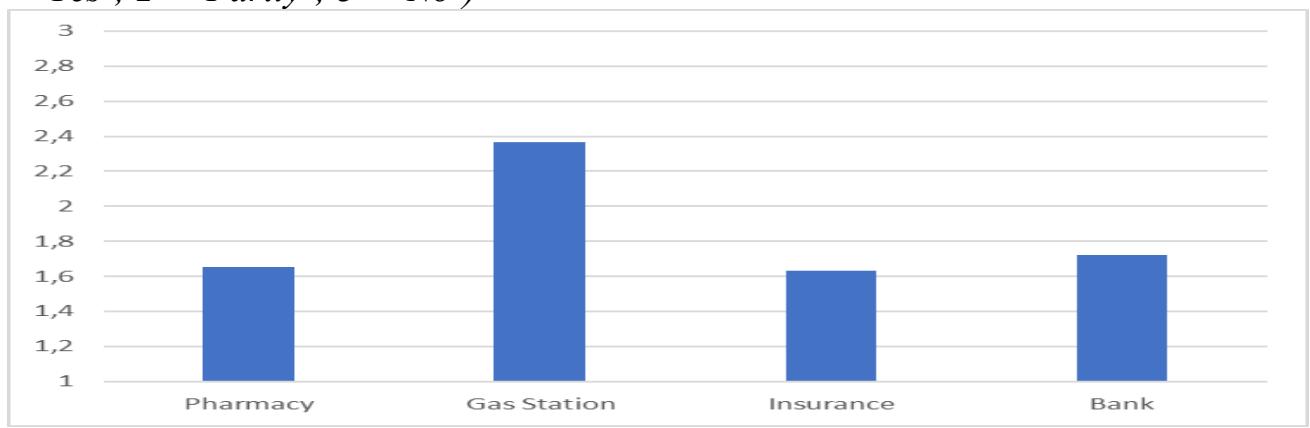

To complement this question, a follow-up was asked in order to ascertain the presence of monopolistic forces within each sector. The results, depicted in Figure 8, show that on average most sectors are characterized by the existence of monopolies, except for the insurance industry where responses tilt towards 'No' on average, albeit slightly. Once again, we find no significant differences in responses across sectors (chi-squared statistic $=7.588 ; \mathrm{p}=0.0554$ ).

Figure 8. To what extent do monopolies exist within your sector? (1 - 'Yes'; 2 'Partly'; 3 - 'No')

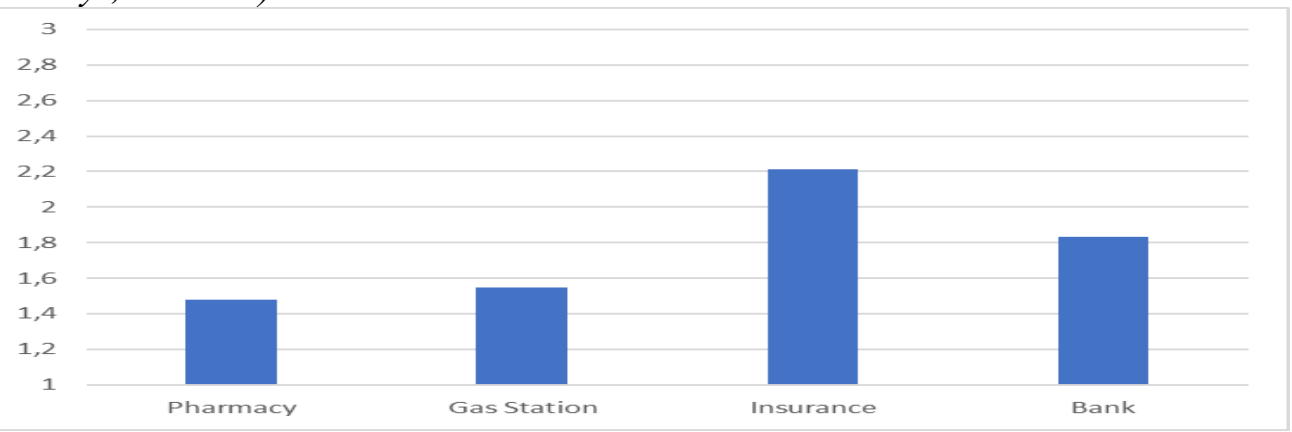

Next, respondents were asked to indicate the extent to which they believe that the Competition Authority in Kosovo has actively intervened in order to protect competition within their sector. As seen below in Figure 9, while most sectors believe that this has been the case, pharmacies overwhelmingly reject this notion, with the average score of 2.78 showing the extent of this belief. In fact, the KruskalWallis test yields statistically-significant results in this case (chi-squared statistic $=20.811 ; \mathrm{p}=0.0001$ ), fueled by the large proportion of 'No' responses from pharmacies, which highlights the perceived lack of adequate intervention by the competition authorities in Kosovo in order to combat anti-competitive practices among pharmacies. 
Figure 9. To what extent has the Competition Authority intervened to protect competition within your sector? (1 - 'Yes'; 2 - 'Partly'; 3 - 'No')

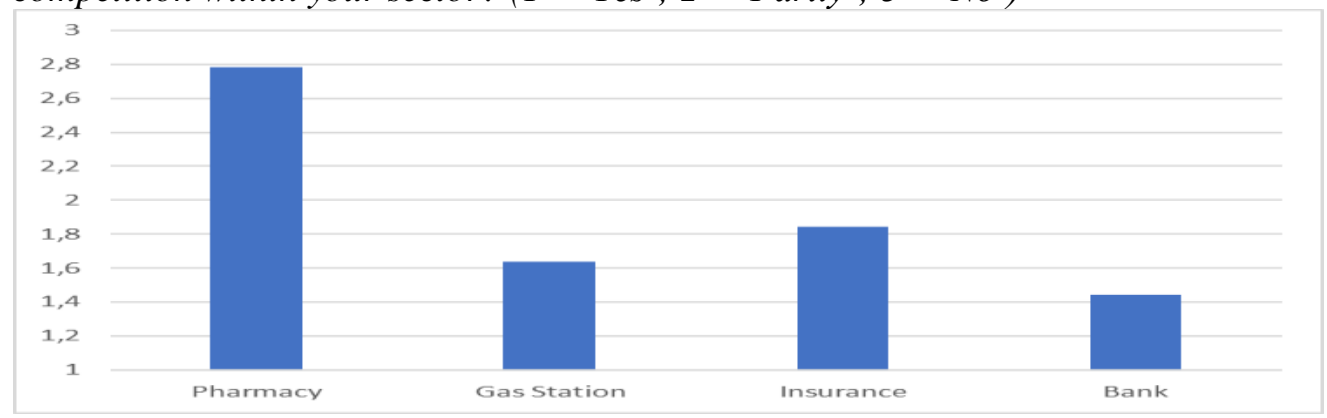

Finally, we also look at the extent to which respondents believe that businesses within their sector have actively engaged in collusive practices or agreements with one another. The results shown in Figure 10 are somewhat mixed, with pharmacies and banks on average tilting towards 'Yes', while gas stations and insurance companies lean more towards 'No', although once again we find no statistically significant differences across means (chi-squared statistic $=6.356 ; \mathrm{p}=0.0955$ ).

Figure 10. To what extent do you believe that businesses within your sector have entered into collusive agreements? (1 - 'Yes'; 2 - 'Partly'; 3 - 'No')

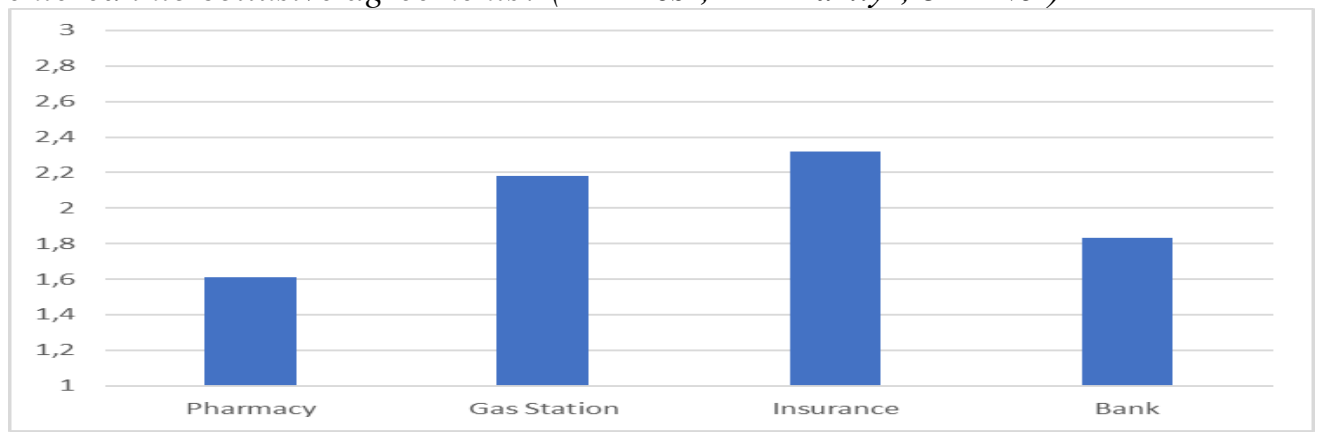

\section{Conclusion}

In this paper, we have sought to analyse the development and protection of competition within key economic sectors within the region of Gjilan in Kosovo. We designed and administered a short questionnaire covering various aspects of competition the effectiveness of existing legislation and public authorities, as well as perceptions regarding the extent of anti-competitive practices and monopolistic power. Respondents from four key sectors were sought out, namely, pharmacies, gas stations, insurance companies and banks, with an overall sample of 71 respondents.

The results show that on average, respondents believe that their sector is relatively well-regulated and competitive, although there are clear areas of improvement, notably with regards to the difficulties encountered when doing business, the 
effectiveness of Kosovo's existing legislative framework and the existence of monopoly power within most sectors. Furthermore, the role of competition authorities in curbing anti-competitive practices needs strengthening, as attested by the results obtained, and more needs to be done when it comes to tackling collusive business practices, particularly among pharmacies and banks.

\section{References:}

Aghion, N. Bloom, R. Blundell, R.G. and Howitt, P. 2002. Competition and Innovation: an Inverted-U Relationship. NBER Working Paper, 9269.

Asllani, G. 2017. Economic Competitiveness Development Challenges in Western Balkan Countries. https://journals.aserspublishing.eu.

Asllani, G. 2016. Competition and Competition rights, Pristine. National Library of Kosovo. Asllani, G. 2012. Market economy and its protection in Kosovo. Mediterranean Competition Bulletin, http://ec.europa.eu/competition/publications/mediterranean/index.html.

Bain, S. 1993. Barriers to new competition. Harvard University Press.

Braun, V. and Clarke, V. 2006. Using thematic analysis in psychology. Qualitative Research in Psychology, 3(2), 77-101, DOI: 10.1191/1478088706qp063oa.

Constitution of the Republic of Kosovo. https://gzk.rks-gov.net.

Dutz, M. and Vagliasindi, M. 2000. Competition Policy Implementation in Transition Economies: An Empirical Assessment. European Economic Review, 44(4-6), 762772 .

Dutz, M. and Hayri, A. 1999. Does More Intense Competition Lead to Higher Growth? CEPR, Discussion Paper No. 2249.

Don, R.K., Sinderen, V. 2008. Measuring the Economic Effects of Competition Law Enforcement. De Economist, 156(4).

Dutz, M. and Vagliasindi, M. 2000. Competition policy implementation in transition Economies. European Competition Network, http://ec.europa.eu/competition/ecn/index_en.

Gavil, A., Kovacic, W. and Baker, B. 2002. Antitrust Law in Perspective: Cases, Concepts and Problems in Competition Policy. American casebook series, $2^{\text {nd }}$ Edition.

Gerber, D. 2001. Law and Competition in Twentieth Century Europe. Oxford University Press.

Krakowski, M. 2005. Competition Policy Works the Effect of Competition Policy on the Intensity of Competition: An International Cross-Country Comparison. HWWA Discussion Paper 332, Hamburg.

Kosovo Agency of Statistics, http://ask.rks-gov.net/.

Kosovo Competition Authority, https://ak.rks-gov.net/.

Kosovo Competition Authority, Agenda for Competitiveness Reforms, https://ak.rks-gov.net.

Levisohn, J. and Petrin, A. 2000. Estimating Production Functions Using Inputs to Control for Unobservable. The Review of Economic Studies Vol. 70, No. 2, pp. 317-341, Published by: Oxford University Press https://www.jstor.org/stable/3648636.

Law on Protection of Competition no. 03 / 1-229, October 7, 2010.

Law No. 04 / L-226 on Amendment and supplementation of Law No. 03 / L-229 on the Protection of Competition.

Morse, J.M. 1995. The significance of saturation. Qualitative Health Research, 5(3), 147 149. 
Romero, A. 2003. Considerations for the Optimal Design of a Competition Enforcement Institution in Guatemala. MBA dissertation, International Development Department, School of Public Policy, University of Birmingham.

OECD. 2015. Competition Law and Policy.

Progress Report for Kosovo. 2018. http://www.mei-ks.net/ .

Regulation No. 1/2003, European Competition Commission.

Regulation no. 1/2003 of the European Commission for Competition.

Samuelson, P. and Nordhaus, W. 1992. For the link between the market economy and competition. Economics 19th Ed. https://www.academia.edu/33624679/Economics_19th_Ed._Paul_Samuelson_Willia m_Nordhaus.pdf.

Tongco, M.D.C. 2007. Purposive Sampling as a Tool for Informant Selection Dolores C.T. file:///E:/Desktops/Old\%20\%20Desktop\%20$\%$ 20Main/University/Thesis\%20at\%20the\%20UOM/Research\%20methods/Qualitativ e\%20sample\%20size/126-454-1-PB.pdf.

UNCTAD. 2010. The Role of Competition Policy in Promoting Economic Development: The Appropriate Design and Effectiveness of Competition Law and Policy. Geneva, $8-12$.

Sengupta, R. and Dube, C. 2008. Competition Policy Enforcement Experiences from Developing Countries and Implications for Investment. OECD Global Forum on International Investment VII.

Voigt, S. 2009. The Effects of Competition Policy on Development: Cross-Country Evidence Using Four New Indicators. The Journal of Development Studies, 45(8), 1225-1248, DOI: 10.1080/00220380902866862

Winston, M and Crandall, W. 2003. Does Antitrust Policy Improve Consumer Welfare? Assessing the Evidence. Journal of Economic Perspectives, 17(4), 3-26. 